\title{
The Use of Human Capital and Limitations of Social Capital in Advancing Economic Security among Immigrant Women Living in Central Alberta, Canada
}

\author{
Choon-Lee Chai ${ }^{1, *}$, Kayla Ueland ${ }^{2}$ and Tabitha Phiri ${ }^{3}$ \\ 1 Department of Sociology, Red Deer College, Red Deer, AB T4N 5H5, Canada \\ 2 Faculty of Law, University of Calgary, Calgary, AB T2N 1N42, Canada; kaueland@ucalgary.ca \\ 3 Center Alberta Immigrant Women's Association, Red Deer, AB T4N 4A3, Canada; Tabitha.phiri@caiwa.ca \\ * Correspondence: chai.choonlee@rdc.ab.ca; Tel.: +1-403-342-3533
}

Received: 19 September 2018; Accepted: 1 November 2018; Published: 5 November 2018

\begin{abstract}
In this research, the challenges of using human capital and the effectiveness of social capital as an alternative resource used by immigrant women from non-English-speaking countries living in Central Alberta for them to attain economic security are studied. Evidence indicates heavy use of bonding social capital by immigrant women-primarily through family, ethnic, and religious networks-as a "survival" resource at the initial stage of settlement. The bonding social capital is relatively easy to access; nevertheless, in the case of visible minority immigrant women living in Central Alberta, bonding social capital has limited capacity in helping them to obtain economic security because their family and friends themselves often lack economic resources. As a result, these immigrant women are expected to compete in the labor market using their human capital to obtain higher-paying jobs. The challenge among immigrant women remains in seeking recognition of non-Canadian credentials, and / or successful acquisition and deployment of Canadian credentials in the primary labor market.
\end{abstract}

Keywords: immigrant women; economic security; human capital; social capital; settlement

\section{Introduction}

Social capital is a form of resource rooted in network relationships. As a concept, it has garnered interest in Canadian policy circles (Policy Research Initiative 2005; Frank 2003) and been incorporated as one of the four resources for well-being by the Organisation for Economic Co-operation and Development (OECD) (2017). Statistics Canada first included some measures associated with the concept of social capital in its 2003 General Social Survey (GSS) on Social Engagement, and continue to include it in the subsequent GSS (Turcotte 2015). According to Scrivens and Smith (2013), the value of social capital from a policy perspective is based on the idea that social relationships of trust and reciprocity have productive value in term of the production of a broad range of well-being outcomes in society.

In immigrant settlement sector, concerted efforts have been taken to cultivate and use social capital to ease the immigrant settlement process, such as in the case of "settlement houses" (Yan and Lauer 2008). The usefulness of social capital, and to some extent the concept of social capital, however, remain ambiguous. According to $\mathrm{Li}$ (2004), the use of social capital is contingent upon the availability of class-based resources within a social community; and as argued by Tanasescu and Smart (2010), social capital cannot replace sound housing policy to meet housing needs of immigrants. Moreover, Bezanson (2006) cautions that the discourse of social capital ignores the gender-bias against women, and is in tandem with the neo-liberal policy of social funding cuts. 
Among immigrants, ethnic or religious affiliations often enable the drawing of social capital situated within the ethnic or religious network. Nevertheless, in a social environment that prizes assimilation, strong ethnic attachment with a limited connection to a broader host community may hinder immigrants' access to information and resources outside of the ethnic community; this is an aspect of the "dark side" of social capital (Portes and Landolt 1996).

This qualitative research, through narratives of immigrant women, fills an important gap in advancing our understanding of the condition of economic security, and the use of human and social capitals, among immigrant women living in Central Alberta, which is composed of a small urban center, Red Deer, and surrounding rural communities. Red Deer's population has doubled in the last three decades and is nearing a population of 100,000 (City of Red Deer 2016). The immigrant population has grown from $10.6 \%$ as the percentage of the total population in 2011 to $14.9 \%$ in 2016 . The top five countries of immigrant origin are the Philippines, Ukraine, India, Syria, and Nigeria. The Philippines was the home country to the largest portion of recent immigrants to Red Deer at $55.4 \%$. What this means is Central Alberta is becoming increasingly ethnically and culturally diverse.

Smaller urban centers like Red Deer that are located in rural contexts have lesser labor market opportunities and fewer settlement resources for ensuring smooth social and economic integration, and retaining immigrants in smaller cities remains a challenge not just in Alberta but across Canada (Carter et al. 2008; Citizenship and Immigration Canada 2001, 2007; Derwing and Krahn 2008). Immigrant women face additional challenges since they are in two "negative status groups" as they are both foreign-born and women (Hill 2011). In general, immigrant women have a lower employment rate and income compared to Canadian-born women, and a higher number of them work part-time with a higher prevalence of low-income. They also have fewer local social connections (Hudon 2015). In other words, immigrant women are among the most disadvantaged population with regards to economic security.

The Canadian Council on Social Development defines Economic Security as "an assured and stable standard of living that provides individuals and families with a level of resources and benefits necessary to participate economically, politically, socially, culturally, and with dignity in their community's activities" (Jackson et al. 2002). In their research, the Women's Economic Council identified six key barriers immigrant women faced to economic security: precarious employment, lack of language skills, lack of credential recognition, lack of community support, lack of affordable and accessible childcare, and lack of affordable and adequate housing (Hill 2011).

In this research, the authors identify barriers faced by immigrant women from non-English-speaking countries in their efforts to use their human capital to achieve economic security and argue that the use of social capital cannot compensate for the non-recognition and lack of human capital among immigrant women living in Central Alberta, Canada.

\section{Employment and Earnings of Immigrant Women in Canada}

Female immigrants are important to Canada's economic and population growth. In 2006, they made up around $20 \%$ of both the country's total female population and female labor force and represented $69 \%$ of the overall female population growth since 2001 (Chui 2011). Since female immigrants are a large and growing portion of Canada's identity, there has been much concern and research surrounding their economic security, including employment and income outcomes.

Immigrants are finding it very difficult to obtain employment in Canada's labor market that is equivalent to their skills and experience. This is reflected in the unemployment rates for recent immigrants that are more than double that of those who were born in Canada, even though immigrants are more likely to hold university degrees (Chui 2011). When controlling for gender, the unemployment rate for female immigrants in 2005 was still 1.6\% higher than their female Canadian-born counterparts (Chui 2011), and young immigrant women had the highest unemployment rates out of everyone (Zietsma 2007). While these employment rates start to converge after immigrants have been in Canada longer than ten years, earnings remain incomparable (Zietsma 2007). This could be one of the factors 
contributing to the higher dependency on transfer payments from the government as income for immigrant women (19\%) as compared to Canadian female residents (15\%) (Chui 2011).

Due to the pressure to support their families and their needs, immigrants are being forced to take jobs that require very little skill and education (Somerville and Walsworth 2010) despite being overqualified. Many immigrants reported that they needed to find any job just to survive (survival employment), no matter what it was, or for how long (Creese and Wiebe 2012). This contributes to the fact that immigrants were more likely than Canadians to hold part-time positions involuntarily (Gilmore 2009). However, it was evident that women faced particular difficulties when securing even "survival employment". The manual labor that African women could find and obtain, like cleaning or caregiving, paid less than similar men's work, making it very difficult for women to even "survive" (Creese and Wiebe 2012).

\section{Human Capital, Social Capital, and Economic Integration of Immigrants}

\subsection{Human Capital}

According to human capital theory, individuals compete fairly for their earnings in an "open market ... based on their level of human capital" (Li 2003, p. 101). In other words, an individual's "economic outcomes are determined by the skills and credentials [they bring] to the labor market" (Phythian et al. 2011, p. 131). This seems logical because we expect those individuals with more experience and qualifications to earn more than those with less, and for earnings to be directly correlated to an individual's productivity and potential economic contribution (Li 2003). For Canadian immigrants, human capital, or factors that represent a form of investment that will bring economic returns, are dominantly education/credentials, work experience and English/French language proficiency (Daley 1992). However, this theory maintains that foreign skills and qualifications are non-transferable to the Canadian labor market; so, those immigrants who have higher-level locally obtained credentials, who have more extensive and local work experience, and who can speak an official language fluently are predicted to have the best labor market outcomes (Phythian et al. 2011).

Human capital theory argues that foreign education and work experience are non-transferable to the Canadian labor force because the skills and credentials obtained in foreign countries are not equivalent to Canadian standards (Sweetman 2004), and that visible minorities who have Canadian post-education yield similar returns to their credentials and work experience as their Canadian post-secondary graduate counterparts (Maximova and Krahn 2005; Wanner 1998; Bonikowska et al. 2008). Choice in the postsecondary field of study is also a strong influence of employment success for immigrants. Overall, graduates from higher paid fields at only the college level had better labor market outcomes than those who held bachelor degrees (Sweetman and McBride 2004). Female immigrants' major fields of study, representing 75\% of all immigrant women, included: business, management, public administration, health, parks recreation, fitness, social and behavioral sciences, law, education and humanities, which could be contributing to their lower wages (Chui 2011). Another phenomenon that could contribute to lower earnings for immigrants is Reitz's (2001) finding that the level of education of immigrants did not increase as rapidly as Canadian's between 1981 and 1991. This combined with institutional changes from the emergence of a "knowledge economy" (emphasis on education in the labor market in Canada) means that relative to Canadians, immigrants are obtaining fewer credentials in a market demanding more credentials. By increasing the number of individuals in the labor market with high education, the competition for skilled positions could have introduced upward pressure on immigrants' chances to be underemployed (Garlarneau and Morissette 2008).

Aside from Canadian education and work experience, human capital theory argues that immigrants also need a good grasp of the national language(s), and is one of the most important factors in predicting employment outcomes. Immigrants who cannot fluently speak English or French in Canada were more likely to be unemployed (Thomas 2009). This could be because employers admit that they assume having a name that doesn't sound English means that the potential employee has 
poor communication skills, so they do not even bother asking them for an interview (Oreopoulos and Dechief 2011). When they do obtain employment, Spruck-Wrigley et al. (2009) found a 46\% wage differential between immigrants who speak English fluently and those who do not. This puts immigrant women at a disadvantage because they typically lack the time and energy to learn English once in Canada because they have the double burden of paid and unpaid employment (Boyd 1984; Stewart 2006).

Moreover, almost $30 \%$ of immigrants who didn't speak an official language at work lived below the low-income threshold (Thomas 2009). Kretsedemas (2005) also found that a lack of English proficiency increased wait times for welfare service, which only adds to immigrant poverty. It could be argued that discrimination is the cause for these inequalities, but those who support human capital theory argue that a lack of language proficiency negatively impacts skills valued in the Canadian market, and therefore negatively impacts their employment outcomes. For example, immigrants scored lower (suggesting language difficulties) in literacy, document literacy, numeracy, and problem-solving skills than Canadian-borns, and these skills showed to have a significant impact on earnings (Bonikowska et al. 2008; Ferrer et al. 2004). This has been reflected in the occupations that immigrants hold. Those who speak another language other than English or French were more often found in less skilled occupations, with only twenty industries employing over $40 \%$ of the immigrants who don't speak an official language on the job site (Thomas 2009).

\subsection{Social Capital}

Much of the debate about income and employment disparity between immigrants and native-born Canadians revolves around the issue of the possession of human capital, or lack thereof, among immigrants (Maximova and Krahn 2005; Wanner 1998; Bonikowska et al. 2008; Li and Li 2013). The usage of the point system by the Canadian government in the selection and admission of immigrants under the Federal Skilled Workers program testifies to the importance placed by the Canadian government on human capital in its immigration policy.

However, in the last two decades, social capital begins to be considered as a new form of capital that can be used to promote social development (Grootaert and Bastelaer 2001). It has been explored by the Canadian government as a public policy tool (Frank 2003), and is identified as an important capital, regarding employment entry, to recent immigrants to Canada (Xue 2008).

Bourdieu (1986) defines social capital as "the aggregate of the actual or potential resources which are linked to possession of a durable network of more or less institutionalized relationships of mutual acquaintance and recognition—or in other words, to membership in a group—which provides each of its members with the backing of the collectively-owned capital". Similar to Bourdieu, Coleman (2000) emphasizes social capital as a resource gained from relationships, whether real or potential, much like a 'credit slip'. He argues that social capital helps individuals achieve goals that they cannot achieve on their own. While Coleman discusses several forms of social capital, of interest is his idea of information channels: "Information is important in providing a basis for action [ ... ] which is always in scarce supply. One means by which information can be acquired is by use of social relations" (Coleman 2000, p. 25). It is here that Coleman points out that if you want to be informed of a phenomenon, but don't want to put the work into maintaining and learning about that specific information, you can use social ties that allow you to stay up to date. This is partly because social capital is convertible, where "friendship ties can be used for other purposes, such as information or advice" (Alder and Kwon 2000, p. 94).

Putnam (2000, p. 22) divides social capital into boding and bridging social capitals. Bonding social capital exists among members of similar background such as an ethnic or religious group. Bridging capital, on the other hand, refers to a social connection with outgroup members. For immigrants of minority groups, bridging social capital is crucial to access information and resources resided within the dominant group in the host society and to this extent, the dominant groups need to be welcoming to those from minority groups (Li 2004, p. 186). 
Social capital is thought of as an investment (requiring maintenance) that increases success in actions like economic outcomes, or in other words, an investment with the expectation of future returns (Li 2004; Lin 2001; Alder and Kwon 2000). Unlike human capital, which represents investments in skills, knowledge and certifications, social capital is an "investment in social relationships through which resources of other actors can be accessed or borrowed" (Lin 2001, p. 24). As Portes (1998, p. 7) puts it, "whereas economic capital is in people's bank account and human capital is inside their heads, social capital inheres in the structure of their relationships".

Lin (2001, p. 24) believes that these conceptual views of social capital can be summed up as the "understanding that social capital consists of resources embedded in social relations and social structure, which can be mobilized when an actor wishes to increase the likelihood of success in a purposive action". Lin offers four reasons why social capital works in the successful attainment of financial capital. The first being that the flow of information is facilitated where having social ties in specific upper-level positions provide individuals with "useful information about opportunities and choices otherwise not available" (Lin 2001, p. 20). Secondly, social capital may exert influence on those key individuals who play a critical role in decisions, like hiring. Third, social ties, and the acknowledgment of a relationship between two individuals, are conceived as certifications of an individual's credentials, much like references. Finally, "social relations [ ... ] provid[e] emotional support [and] also public acknowledgment of one's claim to certain resources" (Lin 2001, p. 20).

Although most research tends to focus on the positive outcomes of social capital, Li (2004) maintains that, in the context of ethnic minorities, social capital cannot replace human capital when trying to produce economic gains or trying to obtain economic opportunities. Ethnic minority communities are more likely to have the least amount of financial capital and are less likely to have ties with influential or powerful groups; therefore, social capital may advance these communities in the short-term, but at prolonged costs (Li 2004). Social capital is more "sticky" in its convertibility rate into financial capital compared with human capital (Alder and Kwon 2000). For example, although it is found that social capital is positively associated with income and occupational status, this association is not as strong as between human capital and income (Kanas et al. 2012; Weaver and Habibov 2012). Social capital mainly advances the interests of the communities with the most financial capital by advancing those with money into higher and more privileged positions (Bourdieu 1986). In his analysis, Nakhaie (2007) found that social capital is less useful for the earning of visible minorities. Individualization or weak social ties, ironically, is associated with higher earnings (Raza et al. 2013).

\section{Methodology}

This qualitative research was conducted in collaboration with the Central Alberta Immigrant Women's Association (CAIWA) whose goal is "to raise the level of awareness of Immigrant Women and their families in all aspect of Canadian life, and to assist them in achieving their full potential as members of Canadian Society". In 2012, CAIWA was approved to receive a grant from the Status of Women Canada to implement a three-year project (March 2012 to February 2015) that will build a community plan to help the economic security of immigrant women in Central Alberta. The research was part of the CAIWA project to identify key barriers that immigrant women were facing in Central Alberta to economic security, as well as suggestions that would help alleviate these barriers.

Qualitative data was chosen for this study because of the importance of having a deep understanding of the experiences that female immigrants in Central Alberta were facing. It was imperative to collect a detailed account of how immigrant women perceive and feel about their own economic security by having an "honest, and balanced account of social life from the viewpoint of someone who lives it every day" (Neuman and Robson 2007, p. 116). While positivists criticize qualitative methods because of their concern for transferability (the extent to which findings can be generalized to other situations), Shenton (2004) argues that "although each case may be unique, it is also an example within a broader group and, as a result, the prospect of transferability should not be immediately rejected" (Shenton 2004, p. 69). 
In this research, purposive sampling was used to recruit research participants. Purposive sampling involves "the deliberate choice of an informant due to the qualities the informant possesses. The researcher decides what needs to be known and sets out to find people who can and are willing to provide the information by virtue of knowledge or experience" (Tongco 2007, p. 147). This is a non-probability sampling technique "that is most effective when one needs to study a certain cultural domain with knowledgeable experts within" (Tongco 2007, p. 147). Immigrant women, many of whom were CAIWA clients, were targeted for focus groups and in-depth interviews since they are insiders who are in the best position to know an immigrant woman's experiences with economic security. It was more important to seek individuals who can be "informationally representative" to the project, rather be "statistically representative" (Sandelowski 1995). That is, it is more important to seek individuals who have faced barriers to economic security and have insight into the difficulties that immigrant women in Central Alberta face when trying to be economically secure, rather than seek comparable sample demographics to the immigrant population in Central Alberta. When using purposive sampling, there is no set number of participants that are required for the sample size, as long as the information needed is obtained (Tongco 2007). Nevertheless, in this research that is guided by the phenomenological approach (please see section "Procedure" for more details), it fell between the recommended 10 to 50 phenomenological sample size (Sandelowski 1995, p. 182).

Focus group discussions were first conducted to gain a general understanding of settlement and integration challenges faced by immigrants. Based on the research purpose, focus group information, and literature, an interview guide was prepared (Appendix A) for detailed interviews with immigrant women on how they perceive and feel about their economic security.

\subsection{Participants}

Fifty-one immigrant males and females were recruited. A total of five focus groups were conducted in both Red Deer and Ponoka in Fall 2012. Focus groups were included in the study to create a basic understanding of the positive experiences and barriers that immigrants have faced in their efforts to achieve economic security in Central Alberta. Information obtained through focus group was used to inform the design of the interview guide in this research, and can also compensate for interview limitations and serve the purpose of triangulation (Shenton 2004).

Subsequently, 33 female immigrants participated in semi-structured, in-depth interviews from January to May 2013. Each interview took between one to two hours to complete. The analysis conducted in this paper is limited to immigrant women who were over 18, from non-English-speaking countries, living in Central Alberta, are permanent residents or Canadian citizens and who had lived in Canada for less than ten years (i.e., 22 of the 33 immigrant women interviewed). Key preferences ensured that the sample consisted mainly of immigrants who had experiences with the Canadian labor market and who had economic experiences that were still relevant.

\subsection{Procedure}

Semi-structured life world interviews were conducted. The strength of choosing this type of interview is that it allowed the interviewers to probe and change questions covered depending on the direction of the interview. The freedom to probe allowed the interviewers to explore new themes, or particular themes in-depth. The interviewers needed this freedom to understand "themes of the lived everyday world from the subjects' perspectives" (Kvale and Brinkmann 2009, p. 27). Moreover, although interviews were focused on particular themes with the help of an interview guide, the interviews were non-directive. In this sense, the interviewee was able to lead the interviewer to themes that she found most profound and relevant to her experiences. By keeping the interview open in such a fashion, the interviewers were able to guide participants to certain themes, without giving them specific opinions about those topics (Kvale and Brinkmann 2009).

A phenomenological approach guided data collection and analysis; it was of interest to understand barriers to economic security through the perspectives of immigrant men and women, 
with the assumption that reality is what individuals perceive it to be (Kvale and Brinkmann 2009). Using phenomenology, this study was able to use "life world", "everyday experiences that we live and which we reflect upon" (Bloor and Wood 2006, p. 128) as a source of evidence of the barriers that immigrant women were facing when trying to achieve economic security. This approach is apparent in the interviews conducted because the respondents were asked to describe specific everyday experiences that elicit concrete events of overcoming or facing barriers to economic security. When it came to analysis of data, phenomenology guided the process through meaning condensation. Meanings, like what immigrants perceived as discrimination, were formulated into shorter statements, and used themes (coding) to turn statements from participants viewpoints, into usable data from the researchers' understanding (Kvale and Brinkmann 2009).

Additionally, descriptions of interviewees perceived reality were taken as truth, where the meaning that they gave to a particular situation was more important than the situation itself. For example, the reality of discrimination was not as important as the perceived amount and depth of discrimination an interviewee had felt (the meaning they placed on interactions with others). Throughout the interviews, interviewees were probed for more details to help interviewers interpret experiences felt and lived by the participants. With more descriptions of specific situations, the interviewer is able to "arrive at meanings on a concrete level" (Kvale and Brinkmann 2009, p.30). After interviews were transcribed, the data was coded using Nvivo software (Please refer to Appendix B for a list of coded themes).

For this study, narratives typically started with biographical information, including where the participant was from why they moved to Canada. This was followed by questions about what it was like when they first arrived in Canada (e.g., struggling to get credentials recognized, language barriers, and employer discrimination) and ended with participants talking about what CAIWA could do to help future immigrant women. Most interviews lasted between one to one and a half hours.

The research proposal underwent ethics review and was approved by the Research Ethics Board of Red Deer College. The names of participants are anonymized to protect their privacy.

\section{Results and Analysis}

Table 1 provides a breakdown of regions from which the immigrant women, whose narratives we analyze in this paper, came from. Narratives of immigrant women are weaved to demonstrate challenges faced by them in trying to deploy their human capitals, the failing of which, leads to the entrapment of these women in low paying jobs. This is followed by the analysis of the use of social capital, which as evidenced, is primarily a secondary capital for many of these immigrant women. Examples of immigrant women who managed to obtain Canadian academic credential and succeeded in their career are also presented to highlight structural barriers faced by immigrant women and the importance of Canadian credentials in the face of non-recognition of foreign credentials. Many immigrant women aspire to obtain Canadian credentials but are hampered by barriers often associated with their gender role as a caregiver.

Table 1. Research Participants from non-English-Speaking Countries, by Geographical Regions of Source Country.

\begin{tabular}{lccccccc}
\hline Geographical Regions & $\begin{array}{c}\text { Central/South } \\
\text { America }\end{array}$ & $\begin{array}{c}\text { East } \\
\text { Europe }\end{array}$ & East Asia & $\begin{array}{c}\text { Middle } \\
\text { East/South Asia }\end{array}$ & $\begin{array}{c}\text { Southeast } \\
\text { Asia }\end{array}$ & Africa & Total \\
\hline Number of Participants & 9 & 3 & 3 & 2 & 3 & 2 & 22 \\
\hline
\end{tabular}

\subsection{The Use of Human Capital}

Human capital represents the skills and qualifications valued by Canadian employers. Regrettably, many immigrants possess skills and credentials that are not being recognized, or only partially recognized, in the Canadian labor market. This lead to underutilization of immigrant skills and 
underemployment of immigrants, often to the detriment of immigrant health (Subedi and Rosenberg 2016).

The most prevalent human capital barriers, as conveyed by interviewees in this research, are the lack of English language proficiency, insufficient Canadian work experience, and non-recognition of foreign credentials.

\subsubsection{Lack of English Language Proficiency}

Research has found that immigrant women who spoke official languages fluently also had higher participation rates in the Canadian labor market compared to immigrant women who did not (Preston and Giles 2004). It is apparent that left unaddressed, this barrier substantially diminishes employment opportunities for immigrant women. In this research, many immigrant women felt as though they couldn't express themselves properly because of a lack of English vocabulary; this not only negatively impacted their employment opportunity but also self-esteem.

“... I had low self-esteem. That low self-esteem came from the language barrier ... Because of the barrier, language barrier, I feel like I am not even a five-year-old boy. They can speak well at least; they can get what they want ... five-year-old kids can express all that they have, but in my case, I have more [knowledge and experiences] than them, but I can't bring it out [sic]". (Hyun-Jae, South Korean).

"Yeah, I know if I speak in Chinese, I can get to the very good expression of ... what I'm thinking, of what I'm caring, something like that. But English, I have to speak so directly (simplistically) to say yes or no. I cannot get something in the middle (nuances), you know?" (Xiaolin, Chinese).

Unfortunately, this low self-confidence impedes their ability to practice English because immigrants "don't feel confident to talk with people here" (Lucero, Latin American). For example, one immigrant woman talked about not being able to speak with customers because she was too embarrassed to speak English: "Like, when the customers come in, I'd back off. I'm shy, I don't want to meet them ..." (Adi, African). Another woman shows how this inability to speak to others can affect employment: " ... also with our language barrier [ ... ] we don't have the confidence to apply [for] office work [ ... ] So it's kind of difficult" (Bituin, Filipino).

Even for immigrants who have a sufficient level of English proficiency, there is always this sense that it is inadequate and they need, and work hard, to improve it.

“... everyone says my English is fine, but for me, it's not fine. I still need to improve [and] I'm working on it right now [ ... ] For me, although I can understand [ . . ] but with my accent $[\ldots]$ like strong accent $[\ldots]$ I need to improve and I need to work it out ..." (Bituin, Filipino)

Most often, those who come over with a family feel as though they don't have the time to practice their English. It is in their opinion that they cannot afford the cost (financially and time commitment) of taking English as the Second Language (ESL) classes, even though the classes could increase their chances at getting better-paying jobs: "learning a language is not that easy ... It's time-consuming and effort-consuming [ ... ] Most people give up to be [a] fluent English speaker" (Hyun-Jae, South Korean).

Additionally, despite all of their efforts to improve language skills, some immigrants faced problems with the ESL program in Central Alberta, hindering their language skills. For example, immigrants were limited in the opportunities that ESL offered:

“... I have finished Level 4 [ ... ] I thought I would go to Level 5, but they canceled [ ... ]

So at that time, I lost my way. Because they told us, there is no Level 5 anymore and ... . I ask them, 'Where can I go?' They say, 'We don't know'"' (Farrah, Iraqi). 
Immigrant women cannot get a skilled position due to their language barriers but then cannot practice their English in their unskilled positions. This gives rise to a vicious cycle of lack of English language proficiency that leads to a lack of opportunities to acquire that proficiency: "In my job, I clean, I don't speak. I no practice [English]" (Maria, Latin American). Since most unskilled positions are filled by immigrants and are more labor intensive so they don't need to speak very much English to communicate with co-workers, which can impede their time to practice English:

“95\% of my co-workers speak Filipino. Maybe you are surprised because three months I have worked [ ... ] as you see my language [has not improved]. If I worked with [native born] Canadians, I'm pretty sure my language will be [better] ... " (Farrah, Iraqi).

"At Olymel (a meat processing plant), most of the time [workers] don't have to talk. It's the process that they have to follow. In that case, they just use physical effort there." (Lucero, Latin American).

Being in a situation where support to increase English language proficiency was lacking, some immigrant women took the initiative to find ways to enhance their language proficiency:

“Now I work [at] drive-through, not [cash] till. I want to work there (drive-through), I told them I want to [improve] my language. If ... I work in drive-through windows, it's better for [improving my language] ... " (Adelah, Afghan).

"You know, [we look] for resources [ ... ] renting library books, like children's books, you know with tapes, things like that. And listening to songs and reading the lyrics at the same time just to get, you know, better English. And talking to people, a lot." (Adolfina, Latin American)

In 2006, 70.2\% of immigrants reported a mother tongue other than English or French. In 2016, $72.5 \%$ of immigrants reported having a mother tongue other than English or French (Statistics Canada 2017a). The largest proportion of immigrants reported Chinese languages (18.6\%), followed by Italian (6.6\%), Punjabi (5.9\%), Spanish (5.8\%), German (5.4\%), Tagalog (4.8\%), and Arabic (4.7\%) languages as their mother tongue (Statistics Canada 2017a). Specifically, in 2011, 70.4\% of female immigrants had a non-official mother tongue only. This is an increase of $18.4 \%$ compared to the year 1981, as indicated in Table 2. This degree of language diversity is related to a decreasing proportion of immigrants landing in Canada from Europe (Hudon 2015).

Table 2. Immigrant Women with neither English nor French as a Mother Tongue (Hudon 2015).

\begin{tabular}{ccc}
\hline Year & 1981 & 2011 \\
\hline Immigrant Women with neither English nor French as a Mother Tongue & $52 \%$ & $70.4 \%$ \\
\hline
\end{tabular}

Visible minority immigrant women that we interviewed, in general, possess sufficient language proficiency for casual interactions with family, friends, and to engage in community activities. Their level of official language proficiency, however, is often insufficient for them to secure better jobs or access further education opportunities. According to Anisef et al. (2012, p. vi), even after four years, about $15 \%$ of immigrant women reported they either could not speak or manage to speak an official language poorly. Immigrant women who speak official languages poorly tended to be older at arrival, visible minorities, migrate as family class or refugees, and come from regions in Asia and the Middle East (Anisef et al. 2012). The language training programs provided to immigrant women need to be adjusted to take into account these factors. 


\subsubsection{Lack of Canadian Work Experience}

"Canadian Work Experience" is an elusive term that immigrants often get asked when applying for a job. It refers to the command of technical knowledge situated in the Canadian context. More significantly, it alludes to cultural nuances, or "tacit knowledge" that immigrants are often assumed need to be acculturated to (Sakamoto et al. 2010). New immigrants, men and women alike, are often excluded from Canadian positions because local employers do not value foreign work experience.

In a study, Guo (2013) found that $66 \%$ of Chinese immigrants in Edmonton and Calgary who had not achieved their main goal of immigration cited lack of Canadian work experience as the main obstacle. We encounter the same situation in our research. A participant stated that: "I find it's ... not easy to find a job just because you don't have the Canadian work experience" and suggested "more programs that can help women to have the experience here. Because almost every employer is asking for the Canadian experience when you want to apply for a job." (MeiZhu, Chinese)

One immigrant woman talked about her experience after three months in Canada; although she had a masters from an English speaking country and plenty of teaching experience, she was unable to secure a teaching position in Canada:

"I had those skills ... It was discouraging when they said: 'But [do] you have Canadian experience? ... We need people with some kind of Canadian experience' ... I don't have that Canadian experience [but] just give me the opportunity to show my skills." (Anfinsa, Latin American)

As a strategy, some immigrants take the route of volunteering to gain Canadian experience, as indicated by Sara:

"I felt perhaps they discriminate, but at the same time, I think those people were hiring persons that they don't know ... they wanted to be sure that I had the skills they needed, and I didn't know how to prove that. If a Principal of a school wanted to hire me, it wasn't just because I looked good or I look like a nice person, he wanted to be sure that I had those skills, and I didn't have that proof. It was discouraging when they said, 'but [do] you have Canadian experience?' So I started to look, to go for places for new immigrants and volunteered. I did a lot of volunteering ... " (Sara, African)

While volunteering helped immigrants to increase their social networks and social capital, it does not usually lead to meaningful employment, mostly because volunteering position usually is not closely related to an immigrant volunteer's job expertise (Wilson-Forsberg and Sethi 2015). More targeted job shadowing, training, or skill upgrading will better serve the goal of immigrants' labor market integration.

\subsubsection{Lack of Recognition of Academic Credential}

Many men and women who migrate as skilled workers to Canada found, upon their arrival, that their foreign academic credentials were not fully recognized by the provincial accreditation agencies, education institutions, and Canadian employers. This is alarming since, in 2006, 58\% of male and $49 \%$ of recent female immigrants held credentials at or above the bachelor level (Chui 2011). Out of those who held higher education, only one-third of the most skilled Korean and Filipino women were employed in professional jobs, along with only two-third of the most skilled female immigrants originating from the United States or Romania (Preston and Giles 2004).

Many immigrants have no idea that their credentials wouldn't be recognized: “No, I didn't know anything about it" (Meizhu, Chinese). As a result, without substantial upgrading, they could not practice the professions they previously occupied in their country of origin. The following women had to start from an entry-level position again in order to get back into a position equivalent to the one she held in her country of origin: 
"It's kind of hard you know ... like the transformation from work that I had, and now to have this kind of work, it's different. Even though I got the training [in my country of origin] ... but when I came here in Canada I have to work from scratch." (Bituin, Filipino).

"We applied under the skilled worker status because ... I was getting the highest points for ... my qualifications ... But in reality ... when you enter Canada ... then it's not recognized." (Natalka, Polish)

Additionally, even when immigrants re-certified themselves, some immigrants expressed they didn't have a guaranteed opportunity for employment at their certification level. Boyd and Schellenberg (2007) report that out of all eligible certified medical doctors, $12 \%$ of immigrants were unemployed as compared to only $2 \%$ of Canadian-born. Moreover, while $90 \%$ of Canadian-born who were trained as physicians worked as physicians, only $55 \%$ of foreign-born who were trained as physicians had the same opportunity (Boyd and Schellenberg 2007).

In order to overcome the lack of recognition of foreign credentials, some immigrants seek to acquire Canadian academic credential. Nevertheless, the road to a Canadian academic credential is a challenging one. One of the most discussed topics surrounding immigrant finances was the decision between upgrading credentials or working full-time to support their families. These immigrant women discussed the endless circle between the two choices:

"I don't know how I'm going to be ready for this test (exam). I have to find money (i.e., work) for my family." (Lucho, Latin American).

"If I decide to work full-time [ ... ] I have to leave [my education] because there is no time. I have to work from eight to three p.m., so I have to leave [the learning of] English, I have [ ... ] I have to leave my dreams." (Farrah, Iraqi).

"Yes, it's a big decision [ ... ] you need to think a hundred times [ ... ] focus on your study more or focus more on your work, because staying here in Canada you need an income so you can survive. [Even] if you have that option of studying, how could you support your studies here when you're not working?" (Diwata, Filipino).

“... working full-time and at the same time studying, it's too much and it [stresses] me, so I try to lessen my workload." (Bituin, Filipino).

In addition to paying for tuition and then supporting the family while in school, finding affordable daycare for young children was also difficult. A lack of affordable childcare prevents female and male immigrants alike to upgrade their credentials, receive higher education or expand employment options (Park 2011). This was especially true when immigrants needed daycare to study for credential recognition exams or classes because there are no programs to recognize these needs. These two immigrant women talk about the difficulties that their husbands faced when trying to juggle their children and their studies:

“... if he has to go full-time [study], our children are small, someone has to stay with them or send them to the day home. Then we need the money to pay for the daycare. So he has to work, but [if he does] he cannot study [ ... ] So financially, for us, it is better for him to stay home with the children [... ] and it's just a vicious cycle [... ] So, we've been kind of trying to, trying to get out of this situation that we are in, but it is very hard." (Natalka, Polish).

"He has a very difficult time. He had to work on his thesis, at the same time he had to take care of our young daughter." (Xiaolin, Chinese).

The deployment of human capital by immigrants hinges upon the recognition of foreign credential and work experience. As indicated in Table 3, there is a clear divide in the rate of recognition of foreign 
credential and work experience between immigrant men and women. Four years after landing, only $22 \%$ of female immigrants have their foreign credential, and $23 \%$ of their foreign work experience recognized compared to $33 \%$ and $51 \%$ respectively among immigrant men.

Table 3. Recognition of Foreign Credential and Work Experience among Immigrant Men and Women within Four Years after Landing in Canada (Houle and Yssaad 2010).

\begin{tabular}{ccc}
\hline & Male & Female \\
\hline Foreign Credential Recognized (\%) & 33 & 22 \\
Foreign Work Experience Recognized $(\%)$ & 51 & 23 \\
\hline
\end{tabular}

Studies show that immigrants from English-speaking regions (the United States as well as the United Kingdom-Australia-New Zealand group) had a higher rate of foreign credential and work experience recognition (Houle and Yssaad 2010, pp. 27-28). "Newcomers who were part of a visible minority also had a lower probability of having their work experience recognized compared to their non-visible minority counterparts" (Houle and Yssaad 2010, p. 25). The numbers in Tables 4 and 5 demonstrate the differing outcomes of foreign credential and work experience recognition. While the rate of recognition of foreign credential among the non-visible minority with visible minority immigrants is small, i.e., $29 \%$ and $27 \%$ respectively, there is a significant gap between non-visible and visible minority regarding recognition of foreign work experience, i.e., $50 \%$ and $35 \%$ respectively. There is also a clear difference between Western and non-Western countries when it comes to where an immigrant obtained his/her highest education or last permanent residence, with Western countries being more advantageous.

Table 4. Recognition of Foreign Credential and Work Experience among Visible and non-Visible Minority Immigrants within four years after landing in Canada (Houle and Yssaad 2010).

\begin{tabular}{ccc}
\hline & Non-Visible Minority & Visible Minority \\
\hline Foreign Credential Recognized (\%) & 29 & 27 \\
Foreign Work Experience Recognized (\%) & 50 & 35 \\
\hline
\end{tabular}

Table 5. Recognition of Foreign Credential and Work Experience among Immigrants from Different Countries (Houle and Yssaad 2010).

\begin{tabular}{cccccc}
\hline & \multicolumn{4}{c}{ Predicted Probability of Recognition (\%) } \\
\hline Country & United States & United Kingdom & China & India & Russia \\
\hline Foreign Credential Recognized $(\%)$ & 57 & 54 & 30 & 28 & 34 \\
Foreign Work Experience Recognized $(\%)$ & 78 & 76 & 32 & 42 & 37 \\
\hline
\end{tabular}

The reasons for non-recognition of foreign credential varies-such as they are being discounted as less relevant to the Canadian labor market, barriers of entry procedures in some trades and professions, and unfamiliarity among employers (Houle and Yssaad 2010, p. 18). Nevertheless, Reitz et al. (2014) argue that "there is convincing evidence of the significance of processes of discriminatory disadvantage affecting skilled immigrants" (Reitz et al. 2014, p. 3), and based on cases coming before the Canadian Human Rights Commission, part of the discrimination could be racial (Reitz et al. 2014, p. 20). Guo (2009) argues that discrimination is partly rooted in "epistemological misperceptions of difference and knowledge" that leads to the belief in the inferior knowledge of immigrants from Third World countries.

If immigrants do not have the means to go back to upgrade their education, they are often stuck working low wage positions and basically work to survive. "The salary you can have is fair enough that you can support yourself as a beginner here in Canada ... it's enough to survive ... " (Bituin, Filipino) but insufficient to rebuild their human capital to be fully recognized by Canadian employers and 
obtain higher paying jobs. Table 6 shows the median wages for immigrants from different regions of birth. It is clear that immigrant women consistently earned less than immigrant men, and immigrants from English speaking countries such as Europe and the United States fare better than immigrants from the non-English-speaking region such as East Asia.

Table 6. Regions of Birth and Median Wages for Immigrants in 2015 who landed in 2005 (Statistics Canada 2017b).

\begin{tabular}{cccc}
\hline & \multicolumn{3}{c}{ Regions of Birth } \\
\cline { 2 - 4 } & Europe & United States & East Asia \\
\hline Female Immigrants & $\$ 34,000$ & $\$ 30,000$ & $\$ 24,000$ \\
\hline Male Immigrants & $\$ 50,000$ & $\$ 51,000$ & $\$ 30,000$ \\
\hline
\end{tabular}

\subsection{The Use of Social Capital}

Putnam (2000) divides social capital into two types, i.e., boding and bridging social capitals. The former exists among members of the similar background such as an ethnic or religious group, while the latter relates to a social connection with outgroup members. Evidence gathered in this research points to immigrant women's regular access of bonding capital among church members, relatives or friends, for settlement needs.

One of the key sources of social support received by immigrants in Central Alberta is the church. In Central Alberta, there is a large church presence, "there [are] a lot of Christian people around" (Katerina, Czech) due to the Canadian University College (renamed to Burman University, a Christian university) in addition to the many Catholic and Christian primary schools in the region. It aids the immigrant population for free, often offering clothes, food, and furnishings for their homes. Prevalent in interviews was that church was one of the main sources of emotional (Bashira, African), social (Omario, African), and financial support (Brianne, Latin American). Additionally, the church is a gateway for immigrants to start volunteering and gain Canadian experience: "I volunteered in church ... that helped me, they [provide] good references, so that helped." (Yalda, Pakistani).

Immigrant women occasionally also received assistance from Canadian employers. Employers did this in many ways, which included the example of paying for apprenticeships or courses that bridged unskilled positions, like janitorial work, to skilled positions, like mechanics (Adolfina, Latin American; Adi, African). They also provided temporary free housing (Bayani) or help to find housing (BayaniFilipino; Natalka, Polish; Lucero, Latin American).

However, the family remains the number one support that immigrants used when first coming to Canada. "Canada has a big impact in my mind because all of our relatives are here in Canada" (Diwata, Filipino); plus family helped with housing by either providing free housing or help to find housing, and helped find jobs either through job searching or by providing references and transportation to and from their jobs. The following two immigrant women explain how much their extended family helped their immediate family after landing in Canada, advancing their family's economic security:

"I came to live with my brother, for three months [ . . ] my sister-in-law, she [ . . ] arrang[ed] everything, the schools, the daycare, everything." (Adi, African).

"When we came here, we had a house right away just because [my family] ha[d] a house here. We were able to get all the things that we need [ . . . ] SIN (Social Insurance Number), that kind of things that we needed when we got here [ ... ] Then, going to school, they introduced us to the schools and the church [ ... ] [My family] helped us with that and just everything else, like from cars to where we buy groceries to where we go to shop [ ... ] They suggested which places always hire [ ... ] Superstore [ ... ] or Taco Time. These were just places that they know were hiring. So they recommended those" (Dalisay, Filipino). 
Finally, families "are good resources because they are just no-cost daycare" (Natalka, Polish). Some immigrants flew parents into Canada to help them get established during their first years in Canada: "my mom visited us and stayed with us for one year to take care of my daughter" (Xiaolin, Chinese). Other immigrants acknowledged the disadvantage of not having their family in Canada that greatly affects their ability to work:

"I have to look after my daughter all the time because she also has [ ... ] special needs [ ... ]

I don't have like a family member [who] could look after her." (Meizhu, Chinese).

While the deployment of social capital and the acquisition of its benefits are evident among immigrant women living in Central Alberta, the limitation of social capital in advancing the living standard of immigrant women we interviewed is also obvious. For many immigrant women, the use of social capital is mostly a stopgap option, as they look to upgrade their human capital through Canadian credentials. In other words, social capital in the life of many immigrant women is only a secondary capital in the absence of "recognized" human capital.

\subsubsection{Social Capital as the Secondary Capital}

Immigrant women tended to lack access to positions that were equivalent to their foreign experience and credentials. What these women did then, was acknowledging the fact that they needed to upgrade their credentials to Canadian credentials and as a temporary measure, fall back onto their social capital (most often their ethnic and religion networks) to get low skilled, low paying jobs. For most, they obtained these positions with the hope and planned to ultimately go back to postsecondary school to get the credentials they need to raise their prospect of better employment. However, barriers prevented most of these women from ever upgrading their human capital. In particular, immigrant women found it difficult to ever find the time, or means, to improve their English while holding low skilled positions; moreover, they found it too difficult to bear the costs of upgrading academic credentials because of their low paying jobs.

An example is a woman who also had a degree but did not use or upgrade it when coming to Canada. Instead, with assistance from her friends, she gained employment as a house cleaner, which then led to more cleaning jobs. Unfortunately, her cleaning experience only gains her similar positions, and she has not had the opportunity to secure better employment, despite her desires. She plans on going back to postsecondary to upgrade her credentials as well, but feels like right now would be too difficult due to her lack of English language proficiency:

Interviewee: "In my country [ . . . ] I studied Bachelor [of] Business Administration. I had my own clothing store [ ... ] when I came, I worked in Sears store [ ... ] cleaning [ ... ] wash the bathroom, toilet [ ... ] before that I clean houses [ ... ] My friend had a company that clean, and they hired me."

Interviewer: "What would you like to do, if you could choose any job here in Canada, here in [Central Alberta], what would you like to do?"

Interviewee: "Social work [ . . . ] because I like to help other people ... "

Interviewer: "Once you get some English training?"

Interviewee: "Yes [ ... ] I think in two years. My husband, [took] one year [to practice his English]. He speaks now better [sic]. But in my job, I clean, I don't speak, I no practice [English] [ ... ] [At home] we speak Spanish. [I only] speak English in my class ... "

Interviewer: "Do you plan on going to school to upgrade?"

Interviewee: "Not at this moment, I like to, but at this moment it's difficult [financially]" (Maria, Latin American). 
The next woman came to Canada because her husband had been working as a temporary foreign worker for eight years in Central Alberta. Even though she had a degree in Political Science and worked in a bank in her country of origin, her husband had to help her get a position at his place of employment. This position was too physically demanding, so she was happy to become a janitor after her friend offered to help get her a position. However, she still hopes to make one more career change by doing a short course, ultimately gaining her a position as a Health Care Aid. She believes that she cannot change careers right at this moment because she cannot speak good English (she speaks Spanish at work) and she has children to support (limiting her income and time):

Interviewee: "I went to University [ . . . ] I finished my Political Science [ . . . ] but in Canada, [they] said no [ ... ] you need more study [ ... ] [they said] you need [to learn] more English [ ... ] [For] many people their first work is janitor or clean [ . . ] [they] don't have more opportunity."

Interviewer: "What was your first job, in Canada?"

Interviewee: “My first job [was a laborer] ... "

Interviewer: "How did you find that?"

Interviewee: "My husband [ ... ] helped me [ ... ] for my first job [as a laborer]. But [for] my new job, one friend called me and [asked] 'do you need [to] change job'? [ . . ] [as a janitor] [... ] I said yes ..."

Interviewer: "Do you think that maybe you'll go back to school and finish your degree?"

Interviewee: “No ..."

Interviewer: "Do you plan on ever going back to University?"

Interviewee: "Yeah, but only [for] short [program]. I [would] like to but right now I don't have enough time for more learning [ ... ] for me right now, the problem is the money [ ... ] I don't have the money [to] take courses" (Isabel, Latin American).

\subsubsection{Social Capital as a Class-based Capital}

As argued by Li (2004), the effectiveness of social capital in promoting upward social mobility depends on class resources available within a social network. An immigrant woman, who received a Ph.D. that was recognized by Canada, moved to Canada after actively applying for research positions to many different universities across the globe, but was successful with her application to the University of Toronto, because of her network with an old friend who had information about the availability of positions. The importance of information, highlighted by Coleman (2000), and often obtained by immigrants from family and friends for settlement needs (George and Ferzana 2009), is evident here.

"Yes, I did apply [to] this job position at the University of Toronto [ . . . actually I was trying to contact several labs in the world, also in the US, in Canada, and even in some Europe ones. I got an offer at the University of Toronto. I think one reason I got the [position] [ ... ] [is] because I had an old friend [ ... ] he worked in a similar area with me and I contacted him first, and he introduced that lab at the University of Toronto [ ... ] [A]fter the interview with my supervisor I got that offer so our family decided to move to Canada from Hong Kong after that. That is my story of why we came to Canada after I got my PhD." (Xiaolin, Chinese)

As indicated in the case of Xiaolin, social capital is useful where the network relationship is rich in class-based resources. This combines with recognized credential highly increases the chances of employment success of new immigrants in Canada. Conversely, a lack of recognized human capital is 
highly detrimental to labor market success. Li (2008) investigated the extent to which social capital can make up for lack of Canadian credential, and found that the benefits of social capital have been overstated by many researchers, who argue that "ethnic connections are seen as a compensation for market disadvantages". In particular, he found that there is no evidence supporting the claim that ethnic social capital can mitigate the effects of a credential deficit.

In the following case, an immigrant woman upgrades her human capital in all three areas: language proficiency, work experience (through practicum), and Canadian credentials. She talks about not wanting to pursue the same degree she held in her country of origin, so she pursued a shorter program that allowed her to integrate into the Canadian labor market faster.

"I already studied for five years business administration [in my country of origin], and I didn't want to do it again here [ . . . ] First I needed a certain level of English language [ ... ] I started to practice the English language [ . . . ] I decided I was going to start studying Early Learning and Childcare [ ... ] In June it was the convocation, and I graduated from that program [ ... ] In my last practicum, they asked me if I can give them my resume and I had an interview with them. After that they called me, and they had the job that I wanted. [When] I finished classes I started working with them. That was wonderful for me [ ... ] I feel satisfied with what I'm doing right now." (Lucero, Latin American).

\section{Limitations of the Study}

One of the limitations of the study is associated with the small sample size and purposive sampling that was used in this research. The research findings presented in this paper are limited to experiences of recent immigrant women from non-English-speaking countries. While this provides a valuable insight into the experiences of the most vulnerable segment of the immigrant community, future study may include experiences of immigrants that belong to dominant groups (English-speaking, and/or non-visible minority) to understand their challenges in their use of human and social capitals.

Associated with small sample size in this research is the possible lack of generalizability of the research findings. While transferability of qualitative research findings to a larger population is not unjustifiable (Shenton 2004, p. 69), nevertheless, in the future, a survey of 300-500 recent immigrant women may be conducted to capture the general profile of immigrant women about their use of human and social capital in Central Alberta.

The geographical context of the research, i.e., a small urban center surrounded by rural communities, also poses a limit to the research findings. Again, while this research fills a knowledge gap about settlement experiences of immigrant women living in the small urban center and rural environment, experiences of immigrant women living in large urban centers can be vastly different from experiences of recent immigrant women living in the rural environment.

\section{Conclusions}

Thomas (2011) found that $26 \%$ of immigrants found their main job through their relatives or friends. Research has also shown that social capital predicts sources of employment, occupational attainment, and immigrant enterprise (Portes 1998). Specifically, the diversity of social networks matter, not the size, because closeness and frequency of contact with networks were not associated with income (Thomas 2011). For example, having a foreign-born partner and contacts, as opposed to an ethnic partner and friends leads to increases in occupational status (Kanas et al. 2012). Also, ethnic enclaves may provide shelter to immigrants, but they are "most relevant to urban economies where a very large and diverse immigrant community offers the immigrants opportunities superior to those found in secondary labor markets" (Pfeffer and Parra 2009, p. 244).

In the case of Central Alberta, the presence of a relatively small number of immigrants of diverse origins making the formation of ethnic enclave unlikely, and among ethnic minorities, strong co-ethnic ties may "reduce opportunities because of social isolation from employment information in mainstream society" (Li 2004, p. 11). This means that the strength and intensity of social ties in and of itself do not 
define the value of social capital an individual has. In general, the availability of resources embedded within a social network is key, and "those who are most advantaged in market access benefit from strong network ties, whereas the disadvantaged are best served by weak ties" (Pfeffer and Parra 2009, p. 247).

The findings of this research demonstrate the marginal utility of social capital in promoting the economic well-being of immigrants. In the case of immigrant women in Central Alberta we interviewed, the form of social capital used is primarily bonding capital, and the usefulness of it is limited to the initial stage of settlement, i.e., in securing low paying, often menial, positions that allow immigrant women to survive in a new social environment. In spite of having a high level of foreign academic or non-academic credentials, many of these immigrant women suffer from low income and intend to attain upward social mobility in Canada by pursuing additional credentials that are recognized by Canadian employers. However, a variety of barriers, especially financial burden and childcare obligation that are associated with female gender roles, seriously hinder these women's ability to pursue and obtain Canadian credentials, leaving them in a perpetual state of economic insecurity. In this regard, the social capital at best is only an inferior capital to this group of disadvantaged immigrant women when it comes to obtaining economic security.

Author Contributions: Conceptualization, C.-L.C.; Methodology, C.-L.C. and K.U.; Validation, C.-L.C. and K.U.; Formal Analysis, C.-L.C. and K.U.; Investigation, C.-L.C., K.U., and T.P.; Resources, C.-L.C. and T.P.; Data Curation, C.-L.C. and K.U.; Writing - Original Draft Preparation, C.-L.C. and K.U.; Writing - Review \& Editing - C.-L.C. and K.U.; Visualization, C.-L.C. and K.U.; Supervision, C.-L.C.; Project Administration, C.-L.C. and T.P. Funding Acquisition, Central Alberta Immigrant Women's Association.

Funding: This research is part of a larger project funded by the Status of Women Canada to increase the economic security of immigrant women in Central Alberta.

Conflicts of Interest: The authors declare no conflict of interest.

\section{Appendix A}

Interview Guide

\section{A.1. Biographical}

\section{A.1.1. Background Information}

1. Are you married, do you have children?
a. What is your spouse doing now?
b. What age are your children?

2. Are you full time, part time, casual, unemployed, or a student?
a. What is your present occupation?
b. What other occupations have you held in Canada?

3. What education and occupation did you have in your home country?

4. What other countries had you lived in?

a. What was the easiest country to immigrate to? Why?

5. When did you immigrate to Canada?

6. Why did you choose to immigrate to Canada?

7. What immigration class or program did you come to Canada through?

a. What is your status?

8. Where have you lived in Canada, and why did you move to Red Deer or area? 


\section{A.1.2. Initial Aspiration versus Current Condition}

1. What did you expect when you immigrated to Canada?

a. Has your experience been what you had expected?

2. Do you think immigrating to Canada has increased your quality of life? How so?

\section{A.2. Human Capital}

\section{A.2.1. Language Proficiency}

1. What languages do you speak fluently?

2. Have you attended ESL classes?

b. Were they helpful?

3. In your opinion, what kind of impact does your English language proficiency have on your employment opportunities?

*If working in the Science field, or a professional field that does not involve a lot of interaction with others:

* 1 . Do you believe your field of choice has aided in bridging your language barrier?

* 2. Do you think your language proficiency would become an issue if you had to switch fields?

\section{A.2.2. Work Experience/Education}

*If working:

${ }^{*} 1$. What was the first job that you took?

a. Why did you take it?

b. How long did it take for you to find your first job?

*2. Are you now working in the field of your choice/expertise?

a. If your current occupation is not your chosen field, why did you decide to apply and work in that occupation?

3. When you came to Canada, were your credentials recognized?

a. Were you aware, before you immigrated to Canada, that your credentials might not be recognized?

b. Did you try to get your academic credentials recognized?

c. If you did get your academic credential recognized, to what extent has it been accepted by employers?

d. Can you explain the process to get your credentials recognized?

e. In your opinion, how difficult is the process to try to get your academic credentials recognized?

4. In order to work in your occupation of choice, what upgrading did you or do you need to take?

a. Have you or do you intend to participate in skill upgrading programs?

b. If you have already upgraded, did you find the content to be more difficult when you upgraded your qualifications?

5. Have you attended any other classes/courses?

a. Did they help you to get a job?

\section{A.2.3. Skills}

1. In your opinion, what skills that you obtained in your home country are you actively using now at your job?

2. Do you believe your previous education and work experience helped you to gain and maintain a job in Canada? How so? 
3. Do you have any skills and knowledge you obtained in your home country that could be developed in order for you to have a better/different employment opportunity?

\section{A.3. Social Capital}

\section{A.3.1. Networking}

${ }^{*}$ If working

${ }^{*} 1$. How is your relationship with your colleagues?

a. Do you have colleagues who are also immigrants?

b. Is that important?

2. Did you have friends or family here before you immigrated?

a. What kind of support did your friends or family extend to you when you first arrived?

b. Did your family or friends help you to find a job?

c. Why was that job recommended?

3. How do you feel about interpersonal relationships in Canada, compared to in your home land?

4. How do you make friends here?

a. How difficult is it for you to make friends?

b. Was it important to you to make friends as soon as you came to Canada? How important? Why was it important?

5. Is there a community organization that you have participated in that has been helpful in meeting new people?

a. How did you find out about them?

b. Did you make friends through the organization?

c. Is the organization or your friends more helpful to you in securing employment or helping you economically?

d. If you did not use a community organization in assisting you, where did you go, and how did you find out about them?

- Why did you not, or could not use assistance from a formal source (such as NGO)?

If Muslim: Were you greeted when you first arrived by your community? If so, what sort of help did they offer you? Did you make friends?

6. Do you have children who are working?

a. Did they grow up here?

b. In your opinion, what was the difference between you and your children in getting employment and establishing friendships?

\section{A.3.2. Religious Social Capital}

1. Do you attend church?

a. Would you say that it has been good support?

b. What kind of supports have they offered?

2. Have you made many friends through your church?

a. Are your friends predominantly from church?

3. Would you say that you relied on your church more when you first came to Canada than now?

a. Did/Do you rely on it more than you rely on it in your country of origin?

4. Would you say that your religion has become a more important part of your life than it was in your country of origin? 


\section{A.3.3. Enclave Economy}

1. Are you working in a sector where the workers are predominantly immigrants?

a. Did that help you get a job?

b. Is that a positive thing, in your opinion?

c. Do you believe there is an opportunity to advance for immigrant workers at your job?

2. Do you think your gender or ethnicity influences your decision to work in your field?

\section{A.4. Gender, Ethnicity, and Age}

Experiences or Perceptions about Gender/Racial Discrimination

1. In your opinion, what kind of impact does your gender or ethnicity have on your job opportunities and everyday life?

2. Do you believe your gender or ethnicity prevents you from accessing employment, wages, or promotions that are available to other people?

3. If you have a spouse, could you describe the differences you experienced when securing employment?

4. When applying for a job that you feel you were qualified for and didn't get, did you feel that you didn't get the job because of discrimination?

a. Can you explain why you believe that?

5. If you did get a job, were you treated differently because of your ethnicity or gender? How so?

6. Do you believe that you have faced any discrimination based on your gender or ethnicity?

7. Can you describe a time when you felt discriminated against?

a. What was your response to the situation?

8. Can you think of any other reasons would you be discriminated against?

\section{A.5. Other Barriers}

*If they have children

*2. Does having young children affect your work life or your upgrading opportunities?

3. Is housing an issue for you?

a. How has it positively or negatively impacted you?

\section{A.6. Geographical and Cultural Location of Red Deer}

*For those who have live elsewhere in Canada

${ }^{*} 1$. What is unique about Red Deer and Central Alberta?

a. How do you feel about Central Alberta compared to other places in Canada?

2. In general, how has been your experience of living in a rural community?

3. How do you feel about the size and diversity of the immigrant population in Red Deer?

4. Do you believe that living in an area that is dominated by the oil and gas industry has disadvantaged/advantaged you in gaining employment?

a. In what ways?

\section{A.7. Policy and Programs}

\section{A.7.1. Programs Accessed}

1. What kind of immigrant programs and services are you using now? 
a. How did you find out about them?

b. Are these programs/services helpful or effective? How so?

2. Do you have access to government-funded social programs?

a. Which ones?

3. Do you think Red Deer, compared to other cities, provides adequate programs for immigrant women?

\section{A.7.2. Program Suggestions}

1. What kind of programs and services would you like to see in Red Deer for immigrant women?

\section{A.8. Wrap up}

Future Expectations

1. What would you consider a satisfactory and successful life in Canada?

2. What would make immigrant women's lives better in Central Alberta?

\section{Appendix B}

Themes Used For Coding

\begin{tabular}{l|l}
\hline Themes & Sub-themes \\
\hline Age Discrimination & - \\
\hline Credential Recognition & - \\
\hline Ethnic Discrimination & $\begin{array}{l}\text { By Another Immigrant } \\
\text { By a Canadian }\end{array}$ \\
\hline \multirow{3}{*}{ Gender Discrimination } & Children \\
& Female versus Male Jobs \\
& Gender Differences \\
\hline \multirow{3}{*}{ Human Capital } & Language Proficiency \\
& Canadian Experience \\
\hline Lack of Finances & Credential Recognition \\
\hline \multirow{3}{*}{ Living in Central Alberta } & - \\
\hline \multirow{3}{*}{ Managing Expectation } & Disadvantage of the Oilfield \\
& Lack of Transportation \\
& More Discriminatory \\
\hline Policy as a Barrier & Bureaucracy \\
& Computer Skills \\
& Culture \\
& Employment Adjustments \\
& Expenses \\
& Feelings of Depression \\
& Unaware of Services/Information deficit \\
\hline & - \\
\hline & Church \\
& Employer \\
& Family \\
& Friendships \\
& Services Used \\
\hline
\end{tabular}

\section{References}

Alder, Pual S., and Seok-Woo Kwon. 2000. Social capital: The good, the bad, and the ugly. In Knowledge and Social Capital. Edited by Eric L. Lesser. Wobrun: Butterworth-Heinmann, pp. 89-115.

Anisef, Paul, Robert Sweet, Maria Adamuti-Trache, and Sarah Wayland. 2012. Explaining Self-reported Language Proficiency Gains of Immigrant Women; Ottawa: Citizenship and Immigration Canada. 
Bezanson, Kate. 2006. Gender and the Limits of Social Capital. Canadian Review of Sociology 43: 427-43. [CrossRef] Bloor, Michael, and Fiona Wood. 2006. Keywords in Qualitative Methods: A Vocabulary of Research Concepts. Thousand Oaks: SAGE Publications Inc.

Bonikowska, Aneta, David A. Green, and W. Craig Riddell. 2008. Literacy and the labour market: Cognitive skills and immigrant earnings. In International Adult Literacy Survey; Catalogue no. 89-552-M No. 020; Ottawa: Statistics Canada.

Bourdieu, Pierre. 1986. The forms of capital. In Handbook of Theory and Research for the Sociology of Education. Edited by John Richardson. Westport: Greenwood Press, pp. 241-58.

Boyd, Monica. 1984. At a Disadvantage: The Occupational Attainments of Foreign Born Women in Canada. International Migration Review 18: 1091-1119. [CrossRef] [PubMed]

Boyd, Monica, and Grant Schellenberg. 2007. Re-accreditation and the occupations of immigrant doctors and engineers. In Canadian Social Trends; Catalogue No. 11-008; Ottawa: Statistics Canada.

Carter, Tom, Margot Morrish, and Benjamin Amoyaw. 2008. Attracting Immigrants to Smaller Urban and Rural Communities: Lessons Learned from the Manitoba Provincial Nominee Program. Journal of International Migration E Integration 9: 161-83.

Chui, Tina. 2011. Immigrant Women. In Women in Canada: A Gender-based Statistical Report, 6th ed.; Catalogue no. 89-503-X; Ottawa: Statistics Canada.

Citizenship and Immigration Canada (CIC). 2001. Towards a More Balanced Geographical Distribution of Immigrants. A Special Study by Strategic Planning, Policy, and Research. Available online: http: / / publications.gc.ca/collections/Collection/Ci51-109-2002E.pdf (accessed on 8 October 2018).

Citizenship and Immigration Canada (CIC). 2007. Attracting and Retaining Immigrants: A Toolbox of Ideas for Smaller Centres, 2nd ed. Available online: https://www.alberta.ca/assets/documents/attracting-andretaining-immigrants-toolbox.pdf (accessed on 8 October 2018).

City of Red Deer. 2016. Statistics and Demographics (Federal Census). Available online: http:/ /www.reddeer.ca/ media/reddeerca/about-red-deer/statistics-and-demographics/Immigration-Population-740X572.png (accessed on 8 October 2018).

Coleman, James S. 2000. Social Capital in the Creation of Human Capital. In Knowledge and Social Capital. Edited by Eric L. Lesser. Woburn: Butterworth-Heinmann, pp. 17-42.

Creese, Gillian, and Brandy Wiebe. 2012. 'Survival employment': Gender and deskilling among African immigrants in Canada. International Migration 50: 56-76. [CrossRef]

Daley, Dennis M. 1992. Paths of Glory and the Glass Ceiling: Differing Patterns of Career Advancement among Women and Minority Federal Employees. Public Administration Quarterly 20: 143-62.

Derwing, Tracey M., and Harvey Krahn. 2008. Attracting and Retaining Immigrants Outside the Metropolis: Is the Pie too Small for Everyone to have a Piece? The Case of Edmonton, Alberta. Journal of International Migration E Integration 9: 185-202.

Ferrer, Ana, David A. Green, and W. Craig Riddell. 2004. The Effect of Literacy on Immigrant Earnings. The Journal of Human Resources XLI: 380-410.

Frank, Jeff. 2003. Making Social Capital Work for Public Policy. Horizons 6: 3-6.

Garlarneau, Diane, and René Morissette. 2008. Immigrants' Education and Required Job Skills. In Perspectives; Catalogue no. 75-001-X; Ottawa: Statistics Canada.

George, Usha, and Chaze Ferzana. 2009. Tell Me What I Need to Know: South Asian Women, Social Capital and Settlement. International Migration and Integration 10: 265-82. [CrossRef]

Gilmore, Jason. 2009. The 2008 Canadian Immigrant: Labour Market: Analysis of Quality of Employment. In The Immigrant Labour Force Analysis Series; Catalogue no. 71-606-X, no. 5; Ottawa: Statistics Canada.

Grootaert, Christiaan, and Thierry van Bastelaer. 2001. Understanding and Measuring Social Capital: A Synthesis of Findings and Recommendations from the Social Capital Initiative. In Social Capital Initiative. Working Paper no. 24. Washington: World Bank.

Guo, Shibao. 2009. Difference, deficiency, and devaulation: Tracing the Roots of non-Recognition of Foreign Credentials for immigrant professionals in Canada. Canadian Journal for the Study of Adult Education 22: 37-52.

Guo, Shibao. 2013. Economic Integration of Recent Chinese Immigrants in Canada's Second-Tier Cities: The Triple Glass Effect and Immigrants' Downward Social Mobility. Canadian Ethnic Studies 45: 95-115. [CrossRef]

Hill, Diane Elizabeth. 2011. Moving Forward: Advancing the Economic Security of Immigrant Women in Canada. Thorold: Women's Economic Council. 
Houle, René, and Lahouaria Yssaad. 2010. Recognition of Newcomers' Foreign Credentials and Work Experience. In Perspectives on Labour and Income; Catalogue no. 75-001-X; Ottawa: Statistics Canada.

Hudon, Tamara. 2015. Immigrant Women. In Women in Canada: A Gender-based Statistical Report, 7th ed.; Catalogue no. 89-503-X; Ottawa: Statistics Canada.

Jackson, Andrew, Spyridoula Tsoukalas, Laura Buckland, and Sylvain Schetagne. 2002. The Personal Security Index, 2002: After September 11th. Ottawa: Canadian Council on Social Development.

Kanas, Agnieszka, Barry R. Chiswick, Tanja van der Lippe, and Frank van Tubergen. 2012. Social Contacts and the Economic Performance of Immigrants: A Panel Study of Immigrants in Germany. International Migration Review 46: 680-709. [CrossRef]

Kretsedemas, Philip. 2005. Language Barriers and Perceptions of Bias: Ethnic Differences in Immigrant Encounters with the Welfare System. Journal of Sociology and Social Welfare 32: 109-23.

Kvale, Steinar, and Svend Brinkmann. 2009. Interviews: Learning the Craft of Qualitative Research Interviewing, 2nd ed. London: SAGE Publications Inc.

Li, Peter S. 2003. Destination Canada: Immigration Debates and Issues. Don Mills: Oxford University Press.

Li, Peter S. 2004. Social Capital and Economic Outcomes for Immigrant and Ethnic Minorities. Journal of International Migration and Integration 5: 171-90. [CrossRef]

Li, Peter S. 2008. The Role of Foreign Credentials and Ethnic Ties in Immigrants' Economic Performance. Canadian Journal of Sociology 33: 291-310.

Li, Peter S., and Eva Xiaoling Li. 2013. Decomposing Immigrants' Economic Integration in Earnings Disparity: Racial Variations in Unexpected Returns. Canadian Ethnic Studies 45: 81-94. [CrossRef]

Lin, Nan. 2001. Social Capital: A Theory of Social Structure and Action. Port Chester: Cambridge University Press.

Maximova, Katerina, and Harvey Krahn. 2005. Does Race Matter? Earnings of Visible Minorities Graduates from Alberta Universities. The Canadian Journal of Higher Education 35: 85-110.

Nakhaie, M. Reza. 2007. Ethnoracial Origins, Social Capital, and Earnings. Journal of International Migration and Integration 8: 307-25. [CrossRef]

Neuman, W. Lawrence, and Karen Robson. 2007. Basics of Social Research: Qualitative and Quantitative Approaches. Toronto: Pearson Education Canada Inc.

OECD. 2017. How's Life? 2017: Measuring Well-being. Paris: OECD Publishing.

Oreopoulos, Philip, and Diane Dechief. 2011. Why Do Some Employers Prefer to Interview Matthew, But Not Samir? Metropolis British Columbia Working Paper Series No. 11-23. Burnaby, BC, Canada: Metropolis British Columbia.

Park, Jungwee. 2011. Job-related Training of Immigrants. In Perspectives on Labour and Income; Catalogue no. 75-001-X; Ottawa: Statistics Canada.

Pfeffer, Max J., and Pilar A. Parra. 2009. Strong Ties, Weak Ties, and Human Capital: Latino Immigrant Employment Outside the Enclave. Rural Sociology 74: 241-69. [CrossRef]

Phythian, Kelli, David Walters, and Paul Anisef. 2011. Predicting Earnings among Immigrants to Canada: The Role of Source Country. International Migration 49: 129-54. [CrossRef]

Policy Research Initiative. 2005. Social Capital as a Public Policy Tool: Project Report; Ottawa: Policy Research Initiative, Government of Canada.

Portes, Alejandro. 1998. Social Capital: Its Origins and Applications in Modern Sociology. Annual Review Sociology 24: 1-24. [CrossRef]

Portes, Alejandro, and Patricia Landolt. 1996. The Downside of Social Capital. The American Prospect 7: 18-21. [CrossRef] [PubMed]

Preston, Valerie, and Wenona Giles. 2004. Employment Experiences of Highly Skilled Migrant Women: Where are They in the Labour Market? Paper presented at the Gender and Work: Knowledge Production in Practice Conference, Toronto, ON, Canada, October 1-2.

Putnam, Robert D. 2000. Bowling Alone: The Collapse and Revival of American Community. New York: Simon and Schuster.

Raza, Muhammad, Roderic Beaujot, and Gebremariam Woldemicael. 2013. Social Capital and Economic Integration of Visible Minority Immigrants in Canada. Journal of International Migration and Integration 14: 263-85. [CrossRef]

Reitz, Jeffrey G. 2001. Immigrant Success in the Knowledge Economy: Institutional Change and the Immigrant Experience in Canada, 1970-95. Journal of Social Issues 57: 579-613. [CrossRef] 
Reitz, Jeffrey G., Josh Curtis, and Jennifer Elrick. 2014. Immigrant Skill Utilization: Trends and Policy Issues. Journal of International Migration E Integration 15: 1-26.

Sakamoto, Izumi, Matthew Chin, and Melina Young. 2010. Canadian Experience, Employment Challenges, and Skilled Immigrants: A Close Look through Tacit Knowledge. Canadian Social Work Journal 10: 145-51.

Sandelowski, Margarete. 1995. Sample Size in Qualitative Research. Research in Nursing and Health 18: 179-83. [CrossRef] [PubMed]

Scrivens, Katherine, and Conal Smith. 2013. Four Interpretations of Social Capital: An Agenda for Measurement. Paris: OECD.

Shenton, Andrew K. 2004. Strategies for Ensuring Trustworthiness in Qualitative Research Projects. Education for Information 22: 63-75. [CrossRef]

Somerville, Kara, and Scott Walsworth. 2010. Admission and Employment Criteria Discrepancies: Experiences of Skilled Immigrants in Toronto. Journal of International Migration and Integration 11: 341-52. [CrossRef]

Spruck-Wrigley, Heide, Jing Chen, Sheida White, and Jaleh Soroui. 2009. Assessing the Literacy Skills of Adult Immigrants and Adult English Language Learners. New Directions for Adult and Continuing Education 121: 5-24. [CrossRef]

Statistics Canada. 2017a. Census in Brief: Linguistic Integration of Immigrants and Official Language Populations in Canada. Available online: https:/ /www12.statcan.gc.ca/census-recensement/2016/as-sa/98-200-x/ 2016017/98-200-x2016017-eng.cfm (accessed on 8 October 2018).

Statistics Canada. 2017b. Income and mobility of immigrants, 2015. The Daily. November 27. Available online: https://www150.statcan.gc.ca/n1/daily-quotidien/171127/dq171127a-eng.htm (accessed on 8 October 2018).

Stewart, Miriam J. 2006. Immigrant Women Family Caregivers in Canada: Implications for Policies and Programmes in Health and Social Sectors. Health and Social Care in the Community 14: 329-40. [CrossRef] [PubMed]

Subedi, Rajendra Prasad, and Mark Warren Rosenberg. 2016. High-skilled Immigrants Low-skilled Jobs: Challenging Everyday Health. The Canadian Geographer 60: 56-68. [CrossRef]

Sweetman, Arthur. 2004. Immigrant Source Country Educational Quality and Canadian Labour Market Outcomes. In Analytical Studies Branch Research Paper Series; Catalogue no. 11F0019MIE-No. 234; Ottawa: Statistics Canada.

Sweetman, Arthur, and Stephan McBride. 2004. Postsecondary Field of Study and the Canadian Labour Market Outcomes of Immigrants and non-Immigrants. In Analytical Studies Branch Research Paper Series; Catalogue no. 11F0019MIE-No. 233; Ottawa: Statistics Canada.

Tanasescu, Alina, and Alan Smart. 2010. The Limits of Social Capital: An Examination of Immigrants' Housing Challenges in Calgary. Journal of Sociology and Social Welfare 37: 97-122.

Thomas, Derrick. 2009. The Impact of Working in a non-Official Language on the Occupations and Earnings of Immigrants in Canada. In Canadian Social Trends; Catalogue no. 11-008-X; Ottawa: Statistics Canada.

Thomas, Derrick. 2011. Personal Networks and the Economic Adjustment of Immigrants. In Canadian Social Trends; Catalogue no. 11-008-X; Ottawa: Statistics Canada.

Tongco, Ma. Dolores C. 2007. Purposive Sampling as a Tool for Informant Selection. Ethnobotany Research and Applications 5: 147-58. [CrossRef]

Turcotte, Martin. 2015. Trends in Social Capital in Canada. In Spotlight on Canadians: Results from the General Social Survey; Catalogue no. 89-652-X2015002; Ottawa: Statistics Canada.

Wanner, Richard A. 1998. Prejudice, Profit, or Productivity: Explaining Returns to Human Capital among Male Immigrants in Canada. Canadian Ethnic Studies 30: 24-55.

Weaver, Robert D., and Nazim Habibov. 2012. Social Capital, Human Capital, and Economic Well-being in the Knowledge Economy: Results from Canada's General Social Survey. Journal of Sociology and Social Welfare 39: 31-53.

Wilson-Forsberg, Stacey, and Bharati Sethi. 2015. The Volunteering Dogma and Canadian Work Experience: Do Recent Immigrants Volunteer Voluntarily? Canadian Ethnic Studies 47: 91-110. [CrossRef]

Xue, Li. 2008. Social Capital and Employment Entry to Recent Immigrants to Canada: Evidence from the Longitudinal Survey of Immigrants to Canada (LSIC); Ottawa: Citizenship and Immigration Canada. 
Yan, Miu Chung, and Sean Lauer. 2008. Social Capital and Ethno-Cultural Diverse Immigrants: A Canadian Study on Settlement house and Social Integration. Journal of Ethnic and Cultural Diversity in Social Work 17: 229-50. [CrossRef]

Zietsma, Danielle. 2007. The Canadian Immigrant Labour Market in 2006: First Results from Canada's Labour Force Survey. In The Immigrant Labour Force Analysis Series; Catalogue no. 71-606-XIE2007001; Ottawa: Statistics Canada.

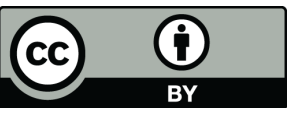

(C) 2018 by the authors. Licensee MDPI, Basel, Switzerland. This article is an open access article distributed under the terms and conditions of the Creative Commons Attribution (CC BY) license (http://creativecommons.org/licenses/by/4.0/). 